\title{
Staurosporine-Induced Apoptosis of Cultured Rat Hippocampal Neurons Involves Caspase-1-Like Proteases as Upstream Initiators and Increased Production of Superoxide as a Main Downstream Effector
}

\author{
Aaron J. Krohn, ${ }^{1}$ Elke Preis, ${ }^{2}$ and Jochen H. M. Prehnn ${ }^{1,2}$ \\ ${ }^{1}$ Center for Interdisciplinary Clinical Research, Junior Research Group "Apoptosis and Cell Death," Westphalian Wilhelms- \\ University, D-48149 Münster, Germany, and 2Department of Pharmacology and Toxicology, Philipps-University, \\ D-35032 Marburg, Germany
}

\begin{abstract}
We induced apoptosis in cultured rat hippocampal neurons by exposure to the protein kinase inhibitor staurosporine (30 nм, $24 \mathrm{hr})$. Treatment with the antioxidant $( \pm)$ - $\alpha$-tocopherol (100 $\mu \mathrm{M})$ or the superoxide dismutase-mimetic manganese tetrakis (4-benzoyl acid) porphyrin $\left(\begin{array}{lll}1 & \mu \mathrm{M})\end{array}\right)$ significantly reduced staurosporine-induced cell death. Using hydroethidine-based digital videomicroscopy, we observed a significant increase in intracellular superoxide production that peaked 6-8 $\mathrm{hr}$ into the staurosporine exposure. This increase occurred in the absence of gross mitochondrial depolarization monitored with the voltage-sensitive probe tetramethylrhodamine ethyl ester. We then prepared extracts from staurosporine-treated hippocampal neurons and monitored cleavage of acetyl-Tyr-Val-Ala-Aspaminomethyl-coumarin and acetyl-Asp-Glu-Val-Asp-AMC, fluorogenic substrates for caspase-1-like and caspase-3-like proteases, respectively. Staurosporine caused a significant increase in caspase-1-like activity that preceded intracellular superoxide production and reached a maximum after $30 \mathrm{~min}$. Caspase-3-like activity paralleled intracellular superoxide pro-
\end{abstract}

During the development of the nervous system, many neurons die because of a physiological process known as programmed cell death (PCD) (Oppenheim, 1991). Growing evidence suggests that features of a conserved cell death program may also play a role in neuronal degeneration after stroke and trauma and in neurodegenerative disorders such as Alzheimer's and Parkinson's disease (Bredesen, 1995; Thompson, 1995). Studies in Caenorhabditis elegans have identified three genes that regulate PCD in the nematode: ced-3, ced-4, and ced-9 (Horvitz et al., 1994). The proteins of the Bcl-2 family are the mammalian homologs of CED-9 and are believed to act upstream of CED-3 and CED-4 (Hengartner and Horvitz, 1994). Apaf-1 is the first identified mammalian homolog of CED-4 (Zou et al., 1997). It participates in the activation of the protease caspase-3, a mammalian homolog of CED-3 (Fernandes-Alnemri et al., 1994). Caspases are a family

\footnotetext{
Received April 9, 1998; revised July 31, 1998; accepted Aug. 5, 1998.

This work was supported by grants from the German Research Foundation (DFG-Forschergruppe "Neuroprotektion") and Alzheimer Forschung Initiative e.V. to J.H.M.P. We thank Professor J. Krieglstein for his support and Dr. C. Culmsee for providing rat brain mRNA.

Correspondence should be addressed to Dr. Jochen H. M. Prehn, Center for Interdisciplinary Clinical Research (IKF), Junior Research Group "Apoptosis and Cell Death," Faculty of Medicine, Westphalian Wilhelms-University, von-EsmarchStrasse 56, D-48149 Münster, Germany.

Copyright (C) 1998 Society for Neuroscience $\quad 0270-6474 / 98 / 188186-12 \$ 05.00 / 0$
}

duction, with peak activity seen after $8 \mathrm{hr}$. Treatment with the corresponding caspase-3-like protease inhibitor acetyl-AspGlu-Val-Asp-aldehyde $(10 \mu \mathrm{M})$ prevented the increase in caspase-3-like activity and staurosporine-induced nuclear fragmentation, but failed to prevent the rise in superoxide production and subsequent cell death. In contrast, treatment with caspase-1-like protease inhibitors reduced both superoxide production and cell death. Of note, antioxidants prevented superoxide production, caspase-3-like protease activity, and cell death even when added $4 \mathrm{hr}$ after the onset of the staurosporine exposure. These results suggest a scenario of an early, caspase-1-like activity followed by a delayed intracellular superoxide production that mediates staurosporine-induced cell death of cultured rat hippocampal neurons.

Key words: oxygen free radicals; superoxide; programmed cell death; apoptosis; caspase-1; caspase-3; mitochondria; hydroethidine; TMRE; vitamin E; superoxide dismutase; neuroprotection of cysteine proteases that specifically cleave proteins after Asp residues (Alnemri et al., 1996). To date, more than 10 caspase family members have been identified, but their relative contribution to PCD still remains unclear (Cohen, 1997; Salvesen and Dixit, 1997).

During apoptosis, caspase-3 and related caspases cleave proteins of the cytoskeleton, the nuclear matrix, transcription factors, and DNA repair enzymes, and they activate apoptosis-specific deoxyribonucleases (Cohen, 1997, Enari et al., 1998). Pharmacological inhibition of caspase-3-like protease activity has been shown to rescue neurons from apoptosis caused by withdrawal of trophic factors or excitotoxic injury (Du et al., 1997; Eldadah et al., 1997). Moreover, caspase-3-deficient mice showed decreased apoptosis in the developing nervous system, suggesting a role for caspase- 3 in the initiation and execution of neuronal apoptosis (Kuida et al., 1996). In contrast, caspase-1 and its closest relatives, caspase-4 and caspase-5, are believed to function primarily in the activation of proinflammatory cytokines (Thornberry et al., 1992; Cohen, 1997). In fact, caspase-1-deficient mice do not exhibit reduced apoptosis in many organs, including the brain ( $\mathrm{Li}$ et al., 1995). However, activation of caspase-1-like proteases and protective effects by specific inhibitors have also been reported in several models of neuronal apoptosis (Gagliardini et al., 1994; 
Milligan et al., 1995; Schulz et al., 1996; Troy et al., 1996; Jordan et al., 1997).

Apart from the proteolytic activity of caspases, an increased formation of oxygen free radicals also contributes to the selfdestruction of neurons undergoing PCD (Kane et al., 1993; Greenlund et al., 1995; Jordan et al., 1995; Atabay et al., 1996, Dugan et al., 1996; Schulz et al., 1996; Prehn et al., 1997; Estévez et al., 1998). An increased formation of superoxide seems to be particularly important, because overexpression of superoxide dismutase (SOD) reduces neuronal apoptosis (Kane et al., 1993; Greenlund et al., 1995; Jordan et al., 1995; Prehn et al., 1997). However, whether free radical production occurs upstream or downstream of caspase activation is still a matter of debate. The present study was performed to investigate the relationship between caspase activation and superoxide production in neuronal apoptosis and to elucidate the relative contribution of both events to the resulting cell death.

\section{MATERIALS AND METHODS}

Cell culture. Cultured hippocampal neurons were prepared from neonatal (P1) Fischer 344 rats as described by Sengpiel et al. (1998). Briefly, the isolated hippocampi were dissected, treated with $0.1 \%$ papain (Sigma, Deisenhofen, Germany) in Leibovitz L-15 medium (Life Technologies, Eggenstein, Germany) at $37^{\circ} \mathrm{C}$ for $20 \mathrm{~min}$, and gently triturated. Afterward, the cell suspension was layered over a trypsin-inhibitor solution, the suspension was centrifuged, and the cells were resuspended. For image analysis, cells were plated onto poly-L-lysine-coated glass coverslips that were placed into $35 \mathrm{~mm}$ Petri dishes (Falcon, Heidelberg, Germany). For cytotoxicity and caspase activity assays, cells were plated onto poly-L-lysine-coated 24-well plates (Nunc, Hamburg, Germany). Cells were plated at a density of $2 \times 10^{5}$ cells $/ \mathrm{cm}^{2}$. Cells were maintained in MEM culture medium supplemented with $10 \% \mathrm{NU}$-serum, $2 \%$ B-27 supplement $(50 \times$ concentrate $), 2 \mathrm{~mm}$ L-glutamine, $20 \mathrm{~mm}$ D-glucose, $26.2 \mathrm{~mm}$ sodium bicarbonate, $100 \mathrm{U} / \mathrm{ml}$ penicillin, and 100 $\mu \mathrm{g} / \mathrm{ml}$ streptomycin (Life Technologies, Gaithersburg, MD). Cells were cultured in a humidified atmosphere of $5 \% \mathrm{CO}_{2}$ and $95 \%$ air at $37^{\circ} \mathrm{C}$. After $1 \mathrm{~d}$ in vitro, the culture medium was exchanged and cultures were treated with $1 \mu \mathrm{M}$ cytosine $\beta$-arabinofuranosid (Sigma) to inhibit the proliferation of non-neuronal cells. All experiments were performed on 8- to 10-d-old cultures. Animal care followed official governmental guidelines.

Induction of apoptosis. Exposure to the protein kinase inhibitor staurosporine is a widely used model to induce apoptosis in neuronal and non-neuronal cells (Falcieri et al., 1993; Jacobson et al., 1993; Bertrand et al., 1994; Koh et al., 1995). We have shown previously that a $24 \mathrm{hr}$ exposure to staurosporine ( $30 \mathrm{~nm}$ ) caused cell death in hippocampal neurons characterized by shrinkage of the cell body, membrane blebbing, chromatin condensation, nuclear pyknosis, and positive labeling of $3^{\prime}$ OH-DNA ends using the terminal deoxynucleotidyl transferase-based dUTP-digoxigenin nick-end labeling (TUNEL) technique (Prehn et al., 1997). This cell death could be prevented by $24 \mathrm{hr}$ pretreatments with the protein synthesis inhibitor cycloheximide or the $\mathrm{G}_{1} / \mathrm{S}$ cell cycle inhibitor mimosine (Prehn et al., 1997). For the induction of apoptosis, staurosporine (Sigma; $1000 \times$ stock in dimethylsulfoxide) was added to the culture medium in a final concentration of $30 \mathrm{~nm}$. This concentration has been shown to induce apoptosis in $\sim 50 \%$ of the neuronal population (Prehn et al., 1997). Controls were exposed to the vehicle.

Protocol of cytotoxicity-neuroprotection experiments. For the toxicityneuroprotection experiments, staurosporine $(30 \mathrm{~nm})$ was added to the culture medium for $24 \mathrm{hr}$. To exclude the possibility that neuroprotective drugs were delaying rather than preventing neuronal cell death, the $24 \mathrm{hr}$ exposure period was followed by a $24 \mathrm{hr}$ recovery period $(24 \mathrm{hr}$ exposure $+24 \mathrm{hr}$ recovery). To this end, the staurosporine-containing medium was aspirated, and the cultures were washed and maintained for a further 24 $\mathrm{hr}$ in astrocyte-conditioned culture medium. Neuroprotective drugs were added $60 \mathrm{~min}$ before exposure to staurosporine unless stated otherwise and were present during the staurosporine exposure only.

Estimation of cell survival. In the cytotoxicity-neuroprotection experiments, cell death was analyzed using the trypan blue dye exclusion method. Uptake of trypan blue indicates membrane leakage, an endpoint of neuronal degeneration that also occurs after neuronal apoptosis in vitro ("secondary necrosis"). Cells were washed once with PBS and then were exposed to trypan blue (0.5\% in PBS) for a period of $5 \mathrm{~min}$. Only darkly stained neurons were considered damaged. A total number of 400-500 neurons were counted in three to four randomly chosen subfields. Cell counts were performed by two investigators and without knowledge of the respective treatments.

Hoechst 33258 staining of nuclear chromatin. Apoptotic cells undergo chromatin condensation, which can be visualized using the DNA-binding fluorescent dye Hoechst 33258. After treatment with staurosporine for the indicated period of time, cells were fixed with $4 \%$ formaldehyde in PBS at $37^{\circ} \mathrm{C}$ for $15 \mathrm{~min}$, permeabilized with ethanol/acetic acid (19:1) at $-20^{\circ} \mathrm{C}$ for $15 \mathrm{~min}$, and washed with PBS. Cells were then exposed to 1 $\mu \mathrm{g} / \mathrm{ml}$ Hoechst 33258 (Sigma) in PBS at room temperature for $15 \mathrm{~min}$. Cultures were washed three times in PBS, and ProLong Anti-Fade reagent (Molecular Probes, Leiden, The Netherlands) was added to the cells according to the manufacturer's instructions. Cells were visualized with an Axiovert 135 fluorescence microscope (Zeiss, Oberkochen, Germany) with UV illumination from a $50 \mathrm{~W}$ xenon arc using a $40 \times$ fluorescence objective. Optical filters were as follows: excitation of 365 $\mathrm{nm}$, dichroic mirror of $395 \mathrm{~nm}$, and emission $420 \mathrm{~nm}$. Nuclei of control cells appeared round to oval, with a septate pattern of blue fluorescence. During the exposure to staurosporine, nuclei became increasingly bright, decreased in size, and fragmented into apoptotic bodies. Normal nuclei, nuclei exhibiting increased Hoechst 33258 fluorescence caused by chromatin condensation, and fragmented nuclei were counted in 10 randomly chosen subfields per culture dish. Because increased Hoechst 33258 fluorescence might indicate reversible nuclear condensation, only fragmented nuclei were considered "apoptotic."

Hydroethidine-based detection of intracellular superoxide production. The cell-permeant probe hydroethidine (HEt) is oxidized by superoxide to a fluorescent product, ethidium (Et). Et is retained intracellularly, thus allowing semiquantitative estimations of cellular superoxide production (Rothe and Valet, 1990; Bindokas et al., 1996). Hydroethidine (Molecular Probes) was prepared as a $10 \mathrm{mg} / \mathrm{ml}$ stock in dry dimethylsulfoxide and stored at $-80^{\circ} \mathrm{C}$. Working stocks $(1 \mathrm{mg} / \mathrm{ml})$ were made in distilled water and were freshly prepared. For estimation of cellular superoxide production, $5 \mu \mathrm{g} / \mathrm{ml}$ hydroethidine was added to the culture medium for a period of $30 \mathrm{~min}$. Cultures were washed three times in HEPES-buffered saline (HBS) (144 mM NaCl, $10 \mathrm{~mm}$ HEPES, $2 \mathrm{~mm} \mathrm{CaCl}_{2}, 1 \mathrm{~mm} \mathrm{MgCl}_{2}$, $5 \mathrm{~mm} \mathrm{KCl}, 10 \mathrm{~mm}$ D-glucose; $320 \mathrm{mOsm}, \mathrm{pH} \mathrm{7.4)}$ and fixed in $4 \%$ formaldehyde as described above. Cellular Et fluorescence was measured using a fluorescence microscope (Axiovert 100 inverted-stage microscope; Zeiss) with attenuated UV illumination from a $75 \mathrm{~W}$ xenon arc. Optics were as follows: excitation of $490 \mathrm{~nm}$, dichroic mirror of $505 \mathrm{~nm}$, and emission $>510 \mathrm{~nm}$. Images were collected using a $40 \times$ fluorescence objective and an intensified CCD camera (C 2400-77, Hamamatsu, Herrsching, Germany). Sixteen frames were averaged for each image. Images were digitized as $256 \times 256$ pixels. Before each experiment, a background image was taken that was later subtracted from the images. Data were analyzed using Argus-50 software (Hamamatsu). Fluorescence intensity data were normalized through standardization of loading procedures, background subtraction, and randomization of the experiments. Alternatively, cellular extracts were prepared using a lysis buffer (10\% SDS, $0.1 \mathrm{~m}$ Tris, pH 7.5), and the Et fluorescence of the cell lysates was quantified using a fluorescent plate reader (FL 500; Biotek, Hamburg, Germany) (excitation $485 \mathrm{~nm}$, emission $530 \mathrm{~nm}$ ). Lysis buffer served as blanks. Protein content was determined using a Pierce BCA Micro Protein Assay Kit (KMF, Cologne, Germany) according to the manufacturer's instructions. Et fluorescence of cell lysates is expressed as fluorescence units per micrograms of protein.

Tetramethylrhodamine ethyl ester-based estimation of mitochondrial membrane potential. Tetramethylrhodamine ethyl ester (TMRE) is a cationic, lipophilic dye that partitions to the negatively charged mitochondrial matrix according to the Nernst equation. Uptake of TMRE has been shown to allow semiquantitative estimations of mitochondrial membrane potential (Ehrenberg et al., 1988). TMRE (Molecular Probes) was prepared as a $10 \mathrm{mg} / \mathrm{ml}$ stock in dry dimethylsulfoxide and stored at $-20^{\circ} \mathrm{C}$. Working stocks $(1 \mathrm{mg} / \mathrm{ml})$ were made in distilled water and were freshly prepared. For estimation of mitochondrial transmembrane potential, cells were incubated with $100 \mathrm{nM}$ TMRE at room temperature for a period of $15 \mathrm{~min}$ in HBS, and cellular TMRE fluorescence was acquired using the above-described fluorescence microscope, filter sets, and imaging system.

Assessment of caspase-1- and caspase-3-like protease activity. After treatment with staurosporine for the indicated periods of time, the 
culture medium was aspirated, and the cells washed three times with HBS and lysed in $200 \mu \mathrm{l}$ of lysis buffer (10 mM HEPES, pH 7.4, $42 \mathrm{~mm}$ $\mathrm{KCl}, 5 \mathrm{~mm} \mathrm{MgCl}$, $1 \mathrm{~mm}$ PMSF, $0.1 \mathrm{~mm}$ EDTA, $0.1 \mathrm{~mm}$ EGTA, $1 \mathrm{~mm}$ DTT, $1 \mu \mathrm{g} / \mathrm{ml}$ pepstatin A, $1 \mu \mathrm{g} / \mathrm{ml}$ leupeptin, $5 \mu \mathrm{g} / \mathrm{ml}$ aprotinin, $0.5 \%$ CHAPS) (Armstrong et al., 1997). Fifty microliters of this extract were added to $150 \mu \mathrm{l}$ of reaction buffer (25 mM HEPES, $1 \mathrm{~mm}$ EDTA, $0.1 \%$ CHAPS, $10 \%$ sucrose, $3 \mathrm{~mm}$ DTT, pH 7.5). The reaction buffer was supplemented either with $10 \mu \mathrm{M}$ Ac-YVAD-AMC, a fluorogenic substrate for caspase-1-like proteases, or with $10 \mu \mathrm{M}$ Ac-DEVD-AMC, a fluorogenic substrate for caspase-3-like proteases (Margolin et al., 1997). Production of fluorescent AMC was monitored over $60 \mathrm{~min}$ using the above-mentioned fluorescent plate reader (excitation $380 \mathrm{~nm}$, emission $460 \mathrm{~nm}$ ). Fluorescence of blanks containing no cellular extracts was subtracted from the values. Caspase-1-like and caspase-3-like activity is expressed as change in fluorescence units per hour per micrograms of protein.

Protein gel electrophoresis-Western blotting. Cells were rinsed with PBS and lysed in Tris-buffered saline containing SDS, glycerin, and protease inhibitors. Protein content was determined using the Pierce BCA Micro Protein Assay Kit, and samples were supplemented with 2-mercaptoethanol and denaturated at $95^{\circ} \mathrm{C}$ for $5 \mathrm{~min}$. Twenty micrograms of protein were separated with $10 \%$ or $12.5 \%$ SDS-PAGE and blotted to nitrocellulose membrane (Protran BA 83; Schleicher \& Schüll, Dassel, Germany). Nonspecific binding was blocked by incubation in PBS containing $2 \%$ bovine serum albumin, $5 \%$ nonfat dry milk, and $0.1 \%$ Tween-20 for $1 \mathrm{hr}$ at room temperature. The blots were then incubated overnight at $4^{\circ} \mathrm{C}$ in blocking buffer with either a mouse monoclonal antibody specific for poly-(ADP-ribose) polymerase (PARP; $116 \mathrm{kDa}$ ) (MCA1522; Serotec, Biozol, Eching, Germany), diluted 1:500, or a rabbit polyclonal antibody specific for pro-caspase-3 (32 kDa) (06-538; Upstate Biotechnology, Biomol, Hamburg, Germany), diluted 1:100. This was followed by incubation with anti-mouse or anti-rabbit IgG-horseradish peroxidase conjugate (1: 5000; Promega, Mannheim, Germany). Antibody-conjugated peroxidase activity was visualized using the SuperSignal chemiluminescence reagent (Pierce).

$R T-P C R$. For detection of caspase-1, caspase-3, and $\beta$-actin mRNA, total cellular RNA was extracted from the hippocampal cultures using the RNEasy kit (Qiagen, Hilden, Germany). Total cellular RNA isolated from secondary cultures of rat cortical astrocytes, from rat brain (striatum and septum), and from mouse brain (neocortex) served as controls. Total cellular RNA was treated with RNase-free DNase I (Promega, Heidelberg, Germany) $(1.0 \mathrm{U} / 50 \mu \mathrm{l})$ for $10 \mathrm{~min}$ at $37^{\circ} \mathrm{C}$. RNA concentration was determined UV-photometrically by absorbance at $260 \mathrm{~nm}$, and purity of the samples was confirmed by $A_{260} / A_{280}$ ratios between 1.7 and 2.0. RNA (600 ng) was subjected to a reverse transcriptase (RT) reaction. RT was performed in $45 \mu \mathrm{l}$ of RT-mix consisting of $100 \mathrm{U}$ MMLV-RT (Life Technologies), $2.2 \mathrm{~mm} \mathrm{MgCl}_{2}$ (Amersham, Braunschweig, Germany), dNTP mix (dATP, dCTP, dGTP, dTTP, $0.2 \mathrm{~mm}$ each; Life Technologies), 4 mm DTT (Life Technologies), 20 U RNaseinhibitor (Promega), $50 \mu \mathrm{M}$ oligo-(T)-primer (MWG Biotech, Ebersberg, Germany), $1 \times$ PCR buffer (Amersham), and RNase-free water. The RT reaction at $37^{\circ} \mathrm{C}$ for $60 \mathrm{~min}$ was followed by $5 \mathrm{~min}$ denaturation at $95^{\circ} \mathrm{C}$. Ten microliters of the cDNA solution were used for the subsequent PCR.

PCR was performed in $50 \mu \mathrm{l}$ of PCR mix containing $0.1 \mathrm{U}$ Taq polymerase (Dianova, Hamburg, Germany), $2.0 \mathrm{~mm} \mathrm{MgCl}_{2}$, dNTP mix (dATP, dCTP, dGTP, dTTP, $0.2 \mathrm{~mm}$ each), $0.3 \mu \mathrm{M}$ each primer (sense and antisense; $\mathrm{MWG}$ Biotech), and $1 \times$ PCR buffer. PCR reaction was performed using a Progene thermocycler (Techne; Thermodux, Wertheim, Germany). The following primers were used: 5'-GGTATTGAGACAGACAGTGG-3' (sense primer) and 5'-CATGGGATCTGTTTCTTTGC-3' (antisense primer) for caspase-3 [expected size of amplification product: 280 bp (Eldadah et al., 1997; Ni et al., 1997)]; 5'-CACATTGAAGTGCCCAAGCT-3' (sense primer) and 5' TCCAAGTCACAAGACCAGGC-3' (antisense primer) for caspase-1 [expected size of amplification product: 300 bp (Eldadah et al., 1997)]; 5'-ATTTGGCACCACACTTTCTACA-3' (sense primer) and 5'TCACGCACGATTTCCCTCTCAG-3' (antisense primer) for $\beta$-actin [expected size of amplification product: 380 bp (Semkova et al., 1996)]. For caspase-1, 30 and 35 cycles were performed, and for caspase-3, 30 cycles of PCR were performed (template denaturation at $95^{\circ} \mathrm{C}$ for $30 \mathrm{sec}$; annealing at $55^{\circ} \mathrm{C}$ for $60 \mathrm{sec}$, primer extension at $72^{\circ} \mathrm{C}$ for $\left.120 \mathrm{sec}\right)$. For $\beta$-actin, 25 cycles of PCR were performed (template denaturation at $95^{\circ} \mathrm{C}$ for $30 \mathrm{sec}$; annealing at $58^{\circ} \mathrm{C}$ for $60 \mathrm{sec}$, primer extension at $72^{\circ} \mathrm{C}$ for 120 $\mathrm{sec})$. Previous studies using RNA extracted from cultured cortical astrocytes or rat brain have shown that 25 cycles of PCR is within the linear range of amplification (C. Culmsee and E. Preis, unpublished data). In each PCR, the last cycle was followed by a final extension step at $72^{\circ} \mathrm{C}$ for 3 min. Fifteen microliters of the PCR product were used for agarose gel electrophoresis $(2 \%)$, and the PCR products were visualized with $0.1 \%$ ethidium bromide under UV transillumination using a CCD camerabased gel documentation system (GelDoc, MWG). In control experiments, extracted RNA from hippocampal neuron cultures was treated with RNase I (Promega; $13.5 \mathrm{U} / \mu \mathrm{g}$ RNA) at $37^{\circ} \mathrm{C}$ for $30 \mathrm{~min}$ and was then subjected to RT-PCR as described. As a second control, RT-PCR was performed with distilled water.

Drugs and substrates. Carbonyl cyanide p-trifluoromethoxyphenylhydrazone (FCCP), staurosporine, and $( \pm)$ - $\alpha$-tocopherol were purchased from Sigma. The caspase inhibitors, acetyl-Asp-Glu-Val-Asp-aldehyde (Ac-DEVD-CHO), acetyl-Trp-Glu-His-Asp-aldehyde (Ac-WEHD$\mathrm{CHO}$ ), acetyl-Tyr-Val-Ala-Asp-aldehyde (Ac-YVAD-CHO), acetyl-TyrVal-Ala-Asp-chloromethylketone (Ac-YVAD-CMK), and Boc-AspCMK (Boc) were from Bachem (Heidelberg, Germany). The fluorogenic substrates for caspase-1-like and caspase-3-like proteases, acetyl-YVADaminomethylcoumarin (Ac-YVAD-AMC) and Ac-DEVD-AMC, and manganese tetrakis (4-benzoyl acid) porphyrin (MnTBP) were purchased from Alexis (Grünstetten, Germany). The 21-aminosteroid trolox was kindly provided by Upjohn (Kalamazoo, MI). Noncaspase protease inhibitors came from Boehringer Mannheim (Mannheim, Germany).

Statistics. Data are given as mean \pm SEM. For statistical comparison, $t$ test or one-way ANOVA followed by Tukey's test were used. For statistical comparison of Et and TMRE fluorescence units, MannWhitney $U$ test and Kruskal-Wallis $H$ test for nonparametric data were used. $p$ values smaller than 0.05 were considered to be statistically significant.

\section{RESULTS}

\section{Antioxidants and caspase inhibitors protect cultured rat hippocampal neurons against staurosporine- induced PCD}

We began our experiments by investigating the effects of antioxidants and caspase inhibitors on long-term survival of the hippocampal neurons ( $24 \mathrm{hr}$ exposure to $30 \mathrm{~nm}$ staurosporine plus 24 hr recovery). We have shown previously that adenovirusmediated overexpression of SOD-1 protected cultured rat hippocampal neurons against staurosporine-induced cell death (Prehn et al., 1997). In agreement with this finding, staurosporine neurotoxicity was significantly reduced by $60 \mathrm{~min}$ pretreatment with the antioxidants $( \pm)$ - $\alpha$-tocopherol $(100 \mu \mathrm{M})$ and trolox (1 $\mu \mathrm{M})$, or the cell-permeant, superoxide dismutase-mimetic MnTBP $(1 \mu \mathrm{M})$ (Fig. 1A).

Staurosporine-induced cell death was also significantly reduced by a 60 min pretreatment with the cell-permeant, broad-spectrum caspase inhibitor Boc-Asp-CMK (0.1 $\mu \mathrm{M})$ (Fig. 1B). Comparable protective effects were observed in cultures treated with AcYVAD-CHO $(10 \mu \mathrm{M})$ (Fig. $1 B)$ or Ac-YVAD-CMK $(1-10 \mu \mathrm{M})$ (Table 1), reversible and irreversible inhibitors of caspase-1-like proteases, respectively. A 60 min pretreatment with Ac-WEHD$\mathrm{CHO}$, a reversible inhibitor with increased specificity for caspase-1, also reduced cell death (Table 1). In contrast, $60 \mathrm{~min}$ pretreatment with the caspase-3-like protease inhibitor AcDEVD-CHO $(10 \mu \mathrm{M})$ failed to decrease staurosporine-induced cell death (Fig. $1 B)$, even with repeated treatments $(3 \times 10 \mu \mathrm{M}$; data not shown). Other peptide protease inhibitors, including calpain inhibitor I (1-10 $\mu \mathrm{M})$ and leupeptin (1-10 $\mu \mathrm{M})$, also failed to reduce staurosporine-induced cell death (data not shown).

\section{Intracellular superoxide production peaks after 6-8 hr of staurosporine exposure}

We then investigated the time course of superoxide production during the exposure to staurosporine using the oxidationsensitive probe HEt. HEt is a nonfluorescent, cell-permeant probe that is oxidized by superoxide to a fluorescent product, Et 
A

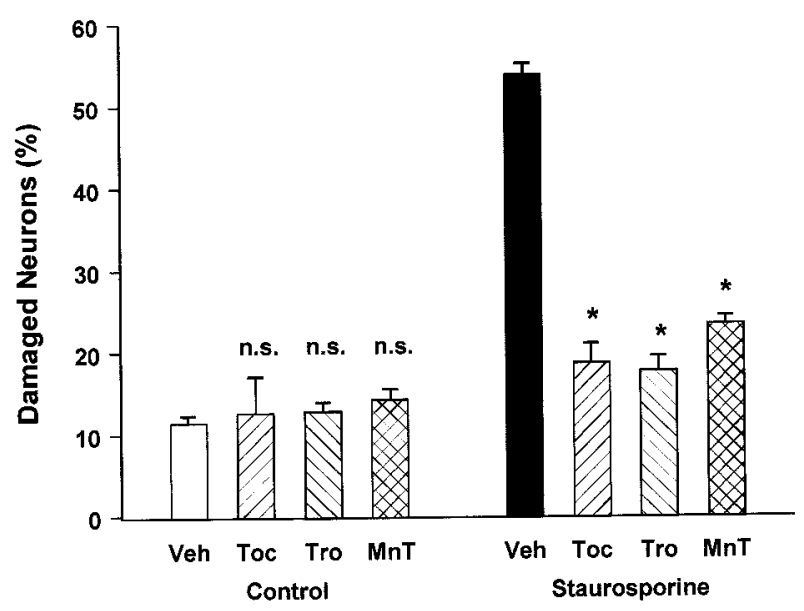

B

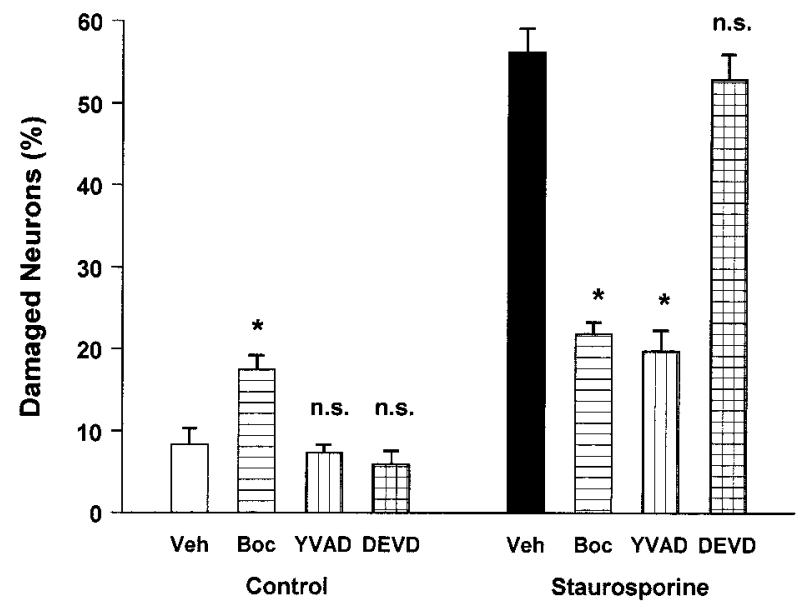

Figure 1. Antioxidants and caspase inhibitors rescue hippocampal neurons from staurosporine-induced PCD. $A$, Protective effect of antioxidants. Cultured rat hippocampal neurons were pretreated for 60 min with $( \pm)$ - $\alpha$-tocopherol $($ Toc $)(100 \mu \mathrm{M})$, trolox $($ Tro $)(1 \mu \mathrm{M})$, the superoxide dismutasemimetic MnTBP $(1 \mu \mathrm{M})$, or vehicle $(V e h)$ and were then exposed to $30 \mathrm{~nm}$ staurosporine for $24 \mathrm{hr}$. Afterward, the staurosporine-containing medium was aspirated, drug treatments were discontinued, and cultures were washed and maintained for a further $24 \mathrm{hr}$ in astrocyte-conditioned culture medium. The percentage of damaged neurons was determined by trypan blue exclusion at the end of the recovery period. Data are mean \pm SEM from $n=8-12$ cultures in two to three separate experiments per treatment. $B$, Protective effect of caspase inhibitors. Hippocampal neurons were pretreated for 60 min with the broad-spectrum caspase inhibitor Boc-Asp-CMK $(B o c)(0.1 \mu \mathrm{M})$, the caspase-1-like protease inhibitor Ac-YVAD-CHO (YVAD) (10 $\mu \mathrm{M})$, the caspase-3-like protease inhibitor Ac-DEV D-CHO $(D E V D)(10 \mu \mathrm{M})$, or vehicle and were exposed to staurosporine as described above. Data are mean \pm SEM from $n=8-15$ cultures in two to four separate experiments per treatment. Different from respective controls: ${ }^{*} p<0.05$. n.s., Not statistically significant.

Table 1. Effect of the irreversible, caspase-1-like protease inhibitor AcYVAD-CMK and the reversible inhibitor with increased specificity for caspase-1 Ac-WEHD-CHO on staurosporine-induced cell death in rat hippocampal neurons

\begin{tabular}{lcr} 
& \multicolumn{2}{c}{ Trypan blue-positive } \\
Treatment & $9.3 \pm 4.2$ & $n$ \\
\hline Vehicle (DMSO) & $7.3 \pm 1.9$ & 10 \\
Vehicle $+10 \mu \mathrm{M}$ Ac-YVAD-CMK & & 4 \\
Staurosporine & $61.4 \pm 7.3$ & 9 \\
Staurosporine $+1 \mu \mathrm{M}$ Ac-YVAD-CMK & $21.7 \pm 6.2^{*}$ & 4 \\
Staurosporine $+10 \mu \mathrm{M}$ Ac-YVAD-CMK & $10.1 \pm 3.0^{*}$ & 4 \\
& & \\
Vehicle (DMSO) & $9.7 \pm 3.9$ & 10 \\
Vehicle $+100 \mu \mathrm{M}$ Ac-WEHD-CHO & $11.9 \pm 2.9$ & 4 \\
Staurosporine & & \\
Staurosporine $+10 \mu \mathrm{M}$ Ac-WEHD-CHO & $53.2 \pm 6.9^{*}$ & 4 \\
Staurosporine $+100 \mu \mathrm{M}$ Ac-WEHD-CHO & $37.3 \pm 6.2^{*}$ & 4 \\
\end{tabular}

Cultured rat hippocampal neurons were pretreated for 60 min with Ac-YVADCMK, Ac-WEHD-CHO, or vehicle and were then exposed to $30 \mathrm{~nm}$ staurosporine for $24 \mathrm{~h}$. Afterward, the staurosporine-containing medium was aspirated, drug treatments were discontinued, and cultures were washed and maintained for an additional $24 \mathrm{~h}$ in astrocyte-conditioned culture medium. The percentage of damaged neurons was determined by trypan blue exclusion at the end of the recovery period. Data are means \pm SEM from $n$ cultures in four separate experiments.

*Difference from vehicle-treated, staurosporine-exposed controls: $p<0.05$.

(Rothe and Valet, 1990; Bindokas et al., 1996). Control cultures accumulated Et fluorescence to a small degree, reflecting endogenous superoxide production derived from the mitochondrial respiratory chain (Fig. 2) (Bindokas et al., 1996; Sengpiel et al., 1998). Exposure to staurosporine (30 nM) led to an increase in Et formation that was statistically significant after $30 \mathrm{~min}$ and peaked after 6-8 hr (Fig. 2A). Simultaneous treatment with
( \pm )- $\alpha$-tocopherol $(100 \mu \mathrm{M})$ attenuated staurosporine-stimulated superoxide production (Fig. $2 B$ ). Of note, $( \pm)$ - $\alpha$-tocopherol also reduced staurosporine-induced superoxide production when added $4 \mathrm{hr}$ after the onset of staurosporine exposure (Fig. 2B).

To investigate whether the increase in superoxide was preceded or paralleled by mitochondrial depolarization, hippocampal cultures were exposed to staurosporine and loaded with the voltagesensitive probe TMRE. We observed no decrease in cellular TMRE fluorescence, indicative of mitochondrial depolarization, before or during the peak superoxide production (Table 2). In fact, cellular TMRE fluorescence increased significantly in cultures exposed for $8 \mathrm{hr}$ to staurosporine (Table 2). In addition, staurosporine-exposed neurons still responded with mitochondrial TMRE release on depolarization with the protonophore FCCP $(0.1 \mu \mathrm{M}, 5 \mathrm{~min}$; increase of $45 \pm 12$ Fl.U. in neurons treated for $8 \mathrm{hr}$ with staurosporine vs $45 \pm 6$ Fl.U. in controls; $p>0.1)$.

\section{Intracellular superoxide production precedes nuclear fragmentation and membrane leakage}

Production of superoxide preceded the large increase in nuclear fragmentation, a hallmark of apoptosis. Staining of nuclei with the DNA-binding dye Hoechst 33258 revealed no significant increase in the percentage of apoptotic nuclei up to $8 \mathrm{hr}$ after onset of staurosporine exposure (Fig. $3 A$ ). By $10 \mathrm{hr}, 26.4 \pm 6.3 \%$ of the nuclei were apoptotic $(p<0.05)$ (Fig. $3 A)$. The large increase in nuclear fragmentation, however, occurred after $12 \mathrm{hr}$ of staurosporine exposure (Fig. 3A). Production of superoxide also preceded the large increase in chromatin condensation, which occurred after $10 \mathrm{hr}$ (data not shown).

Cultures were analyzed by trypan blue staining to determine the time course of membrane leakage, an endpoint of neuronal degeneration. The percentage of trypan blue-stained neurons remained indistinguishable from that of control cultures up to 10 hr into the staurosporine exposure (Fig. 3B). By $12 \mathrm{hr}$, there was 


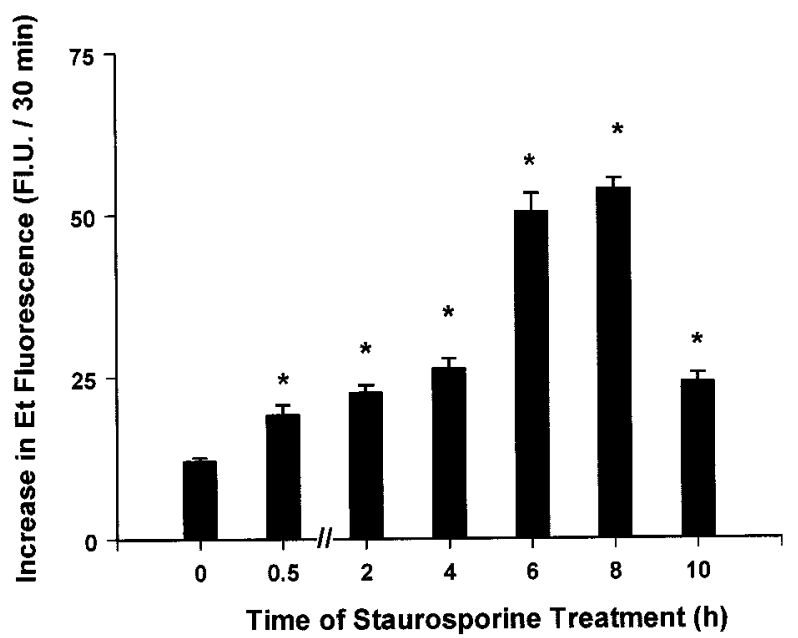

B

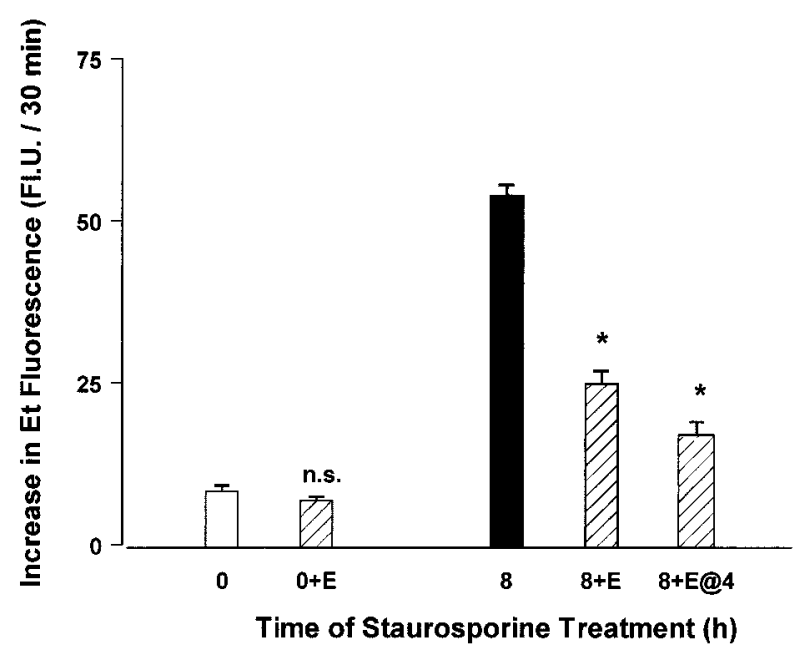

Figure 2. Superoxide production during PCD in rat hippocampal neurons: time course $(A)$ and inhibition by $( \pm)$ - $\alpha$-tocopherol $(B)$. Cultures were treated with staurosporine ( $30 \mathrm{~nm}$; solid bars) or staurosporine plus $( \pm)$ - $\alpha$-tocopherol (vitamin E, $100 \mu \mathrm{M}$; hatched bars) for the indicated periods of time. Alternatively, cultures were treated for $8 \mathrm{hr}$ with staurosporine and received the antioxidant during the last $4 \mathrm{hr}$ of the exposure period $(8+E @ 4)$. Controls were exposed to vehicle. For estimation of intracellular superoxide production, $5 \mu \mathrm{g} / \mathrm{ml}$ hydroethidine was added to the cultures during the last $30 \mathrm{~min}$ of the staurosporine exposure, and ethidium $(E t)$ fluorescence of the neuronal somata was quantified by digital videomicroscopy. Data are mean \pm SEM from $n=57-202$ neurons in two to three separate experiments per treatment. Different from respective controls: ${ }^{*} p<0.05 . n . s .$, Not statistically significant; Fl.U., arbitrary fluorescence units.

\begin{tabular}{|c|c|c|c|}
\hline Treatment (h) & $\begin{array}{l}\text { TMRE fluorescence } \\
\text { (Fl. U.) }\end{array}$ & $n$ & $p$ value \\
\hline 0 & $22.5 \pm 0.6$ & 139 & \\
\hline 0.5 & $21.1 \pm 1.3$ & 29 & n.s. \\
\hline 2 & $23.5 \pm 1.3$ & 26 & n.s. \\
\hline 8 & $28.6 \pm 1.2$ & 78 & 0.01 \\
\hline
\end{tabular}

Cultured rat hippocampal neurons were treated with staurosporine ( $30 \mathrm{~nm}$ ) for the indicated period of time and incubated with $100 \mathrm{~nm}$ TMRE during the last $15 \mathrm{~min}$ of the exposure. Afterward, cultures were washed and TMRE fluorescence of the neuronal somata was recorded and quantified using digital video imaging and Argus 50 software. Data are means \pm SEM from $n$ neurons in four to eight separate experiments per condition. n.s., Not statistically significant; Fl. U., arbitrary fluorescence unit.

a moderate yet statistically significant increase in the percentage of cells showing membrane leakage (Fig. $3 B$ ). At the end of the 24 hr exposure period, $45.1 \pm 2.3 \%$ of the hippocampal neurons were trypan blue positive. Interestingly, when the cultures were maintained for a further $24 \mathrm{hr}$ in astrocyte-conditioned culture medium ( $24 \mathrm{hr}$ exposure plus $24 \mathrm{hr}$ recovery), the percentage of trypan blue-stained neurons increased to $52.9 \pm 2.3 \%(p<0.05$ vs $24 \mathrm{hr}$ exposure only; $n=12$ cultures in three separate experiments) (Fig. 3B).

\section{Biphasic activation of caspases during staurosporine-induced PCD}

To investigate the time course of caspase activation in staurosporine-induced apoptosis, we prepared extracts from staurosporine-treated hippocampal cultures and measured their cleavage of fluorogenic caspase substrates. Ac-YVAD-AMC is cleaved by caspase- 1 and, with lower affinity, by the related caspases, caspase-4 and caspase-5 (Cohen, 1997; Salvesen and Dixit, 1997). Control cultures exhibited no significant YVADcleavage activity (Fig. 4A). Exposure to staurosporine resulted in an early increase in caspase-1-like protease activity that was maximal $30 \mathrm{~min}$ into the staurosporine exposure and returned to baseline levels by $4 \mathrm{hr}$ (Fig. $4 A$ ). RT-PCR confirmed the expression of caspase-1 mRNA in the hippocampal cultures. However, caspase-1 mRNA expression was low in the hippocampal neuron cultures in comparison to cultured cortical astrocytes and brain tissue derived from rat or mouse (Fig. 5A). No PCR products were obtained if extracted RNA from hippocampal neuron cultures was treated with RNase I and was then subjected to RTPCR, or if RT-PCR was performed with distilled water (data not shown). Caspase-1 mRNA did not show significant changes in the level of expression up to $6 \mathrm{hr}$ into the staurosporine exposure (Fig. 5A).

Ac-DEVD-AMC is cleaved by caspase- 3 and its closest relatives, caspase-2 and caspase-7 (Cohen, 1997; Salvesen and Dixit, 1997). Cellular extracts from control cultures showed negligible Ac-DEVD-AMC cleavage (Fig. 4B). Ac-DEVD-AMC cleavage was not different from baseline activity up to $2 \mathrm{hr}$ into the staurosporine exposure. Ac-DEVD-AMC cleavage activity then increased gradually and reached a maximal activity after $8 \mathrm{hr}$ of staurosporine exposure (Fig. 4B). RT-PCR confirmed the expression of caspase-3 mRNA in the hippocampal cultures (Fig. $5 B$ ). No PCR products were obtained if extracted RNA from hippocampal neuron cultures was treated with RNase I (data not shown). As with caspase-1, there was no significant increase or decrease in caspase- 3 mRNA expression up to $6 \mathrm{hr}$ into the staurosporine exposure (Fig. $5 B$ ).

Evidence for the activation of caspase-3-like proteases was also obtained from Western blotting experiments using cytosolic protein extracts of staurosporine-treated hippocampal cultures. The cytosolic content of PARP, a substrate for caspase-3-like proteases, decreased during the exposure to staurosporine as detected with a monoclonal antibody specific for the uncleaved 116 kDa protein (Fig. $6 A$ ). Maximal changes were seen after 4 and 8 hr of exposure. Caspase-3 itself is proteolytically activated by cleavage of its precursor, pro-caspase- 3 , into active subunits. We 
A

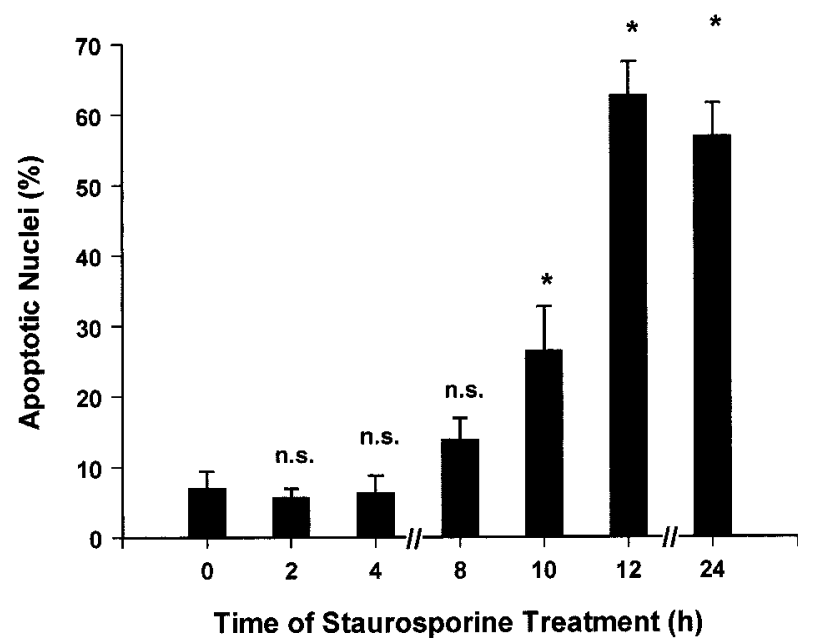

B

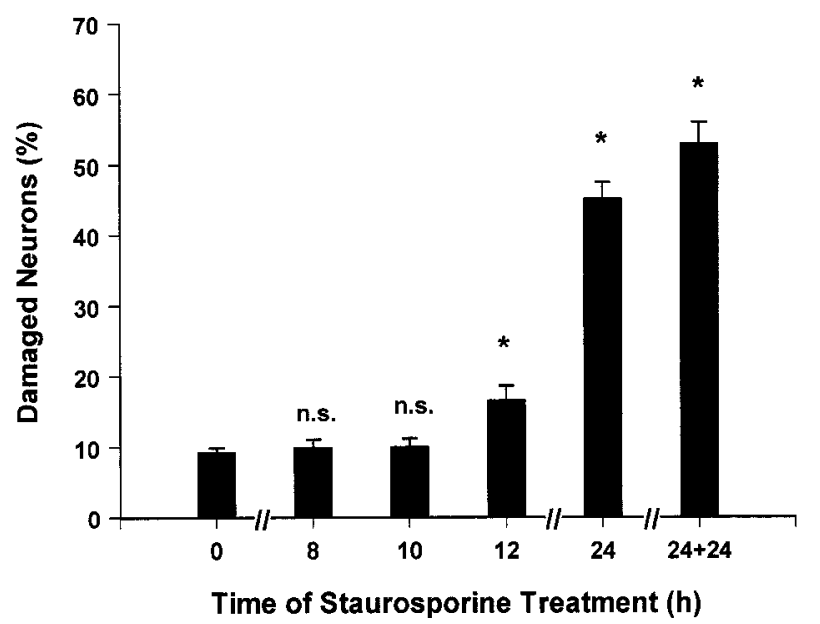

Figure 3. Time course of nuclear fragmentation and membrane leakage in cultured rat hippocampal neurons during exposure to staurosporine. $A$, Hoechst 33258 staining of nuclear chromatin. Cultured rat hippocampal neurons were treated with 30 nM staurosporine for the indicated period of time $(0-24 \mathrm{hr})$. Nuclei were considered apoptotic if they fragmented into apoptotic bodies. Data are mean \pm SEM from $n=4-13$ cultures in three separate experiments. $B$, Trypan blue uptake, indicative of membrane leakage. Data are mean \pm SEM from $n=4-12$ cultures in four separate experiments. Different from controls $(0 \mathrm{hr}):{ }^{*} p<0.05$. n.s., Not statistically significant.

A

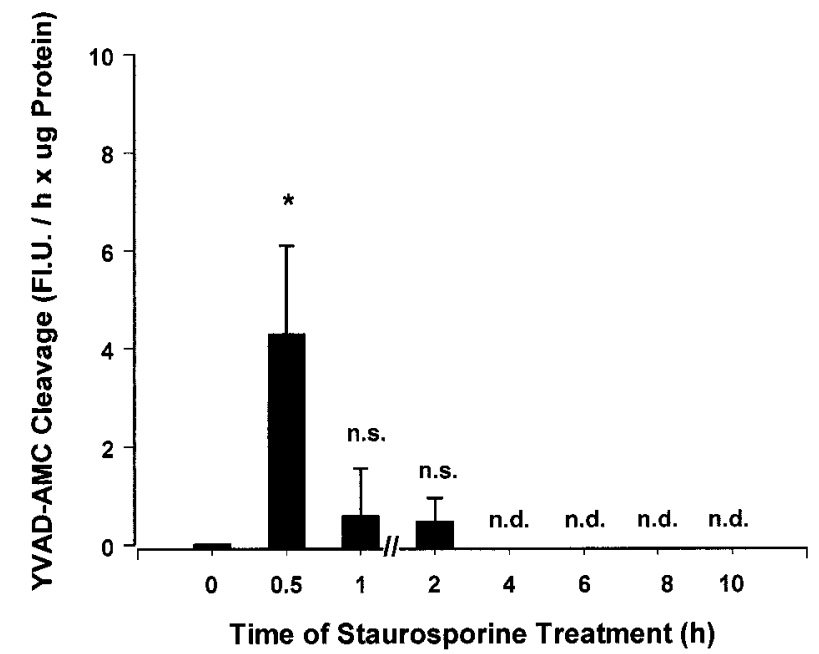

B

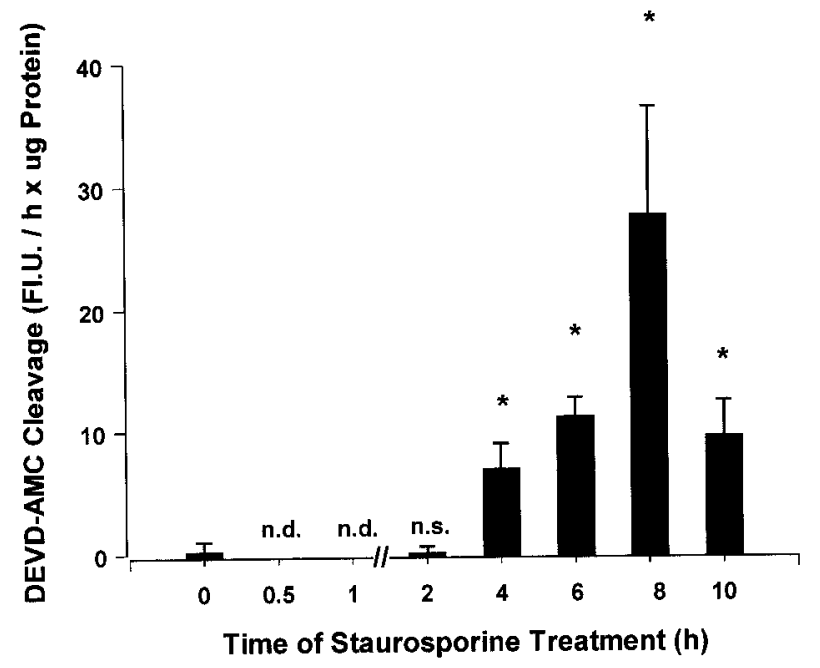

Figure 4. Time course of caspase activity in cytosolic protein extracts from rat hippocampal cultures after treatment with staurosporine. $A$, Caspase-1-like protease activity determined by cleavage of the fluorogenic substrate Ac-YVAD-AMC (10 $\mu \mathrm{M})$. $B$, Caspase-3-like protease activity determined by cleavage of the fluorogenic substrate Ac-DEVD-AMC $(10 \mu \mathrm{M})$. Cultures were treated with staurosporine $(30 \mathrm{nM})$ for the indicated periods of time. Activities are represented as increase in AMC fluorescence per hour per micrograms of protein. Data are mean \pm SEM from $n=10-22$ cultures in three to five separate experiments per condition. Different from controls $(0 \mathrm{hr}){ }^{*}, p<0.05$. n.d., Not detectable; n.s., not statistically significant.

observed a pronounced decrease in the cytosolic content of the 32 $\mathrm{kDa}$ precursor protein during the staurosporine exposure (Fig. $6 B$; compare with Fig. $5 B$ ).

\section{Delayed treatment with antioxidants, but not caspase} inhibitors, prevents staurosporine-induced PCD

We then determined the latest time at which neurons could be protected by antioxidants or caspase inhibitors. Treatment with the irreversible caspase-1-like protease inhibitor Ac-YVADCMK $(10 \mu \mathrm{M})$ immediately after addition of staurosporine still resulted in a significant, albeit reduced protection of the hippocampal neurons (Fig. 7A; compare with Table 1). However, the protective effect of Ac-YVAD-CMK was lost when the treatment was started $2 \mathrm{hr}$ after the onset of staurosporine exposure (Fig.
$7 A$ ). A similar window of protection was observed with the broad-spectrum caspase inhibitor Boc-Asp-CMK (0.1 $\mu \mathrm{M}$; data not shown).

In contrast, ( \pm )- $\alpha$-tocopherol $(100 \mu \mathrm{M})$ prevented cell death when added up to $4 \mathrm{hr}$ after the onset of staurosporine exposure (Figs. 7B, 8). Statistically significant neuroprotective effects were observed even when $( \pm)$ - $\alpha$-tocopherol was added after $8 \mathrm{hr}$ (Fig. $7 B)$. Treatment with $( \pm)$ - $\alpha$-tocopherol $10 \mathrm{hr}$ after addition of staurosporine, i.e., after the peak in superoxide production, failed to show a neuroprotective activity (Fig. $7 B$ ). Treatment with the 21-aminosteroid trolox $(1 \mu \mathrm{M})$ or the SOD-mimetic MnTBP $(1 \mu \mathrm{M}) 4 \mathrm{hr}$ after the onset of the staurosporine exposure also reduced staurosporine-induced cell death (data not shown). 
A

\section{Caspase-1 (30 Cycles)}

MW Ast Ast Rat Rat Mo Mo Hip H3h H6h

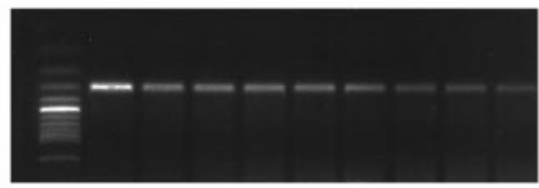

$\Leftarrow 280$ bp

Caspase-1 (35 Cycles)

MW Ast Ast Rat Rat Mo Mo Hip H3h H6h

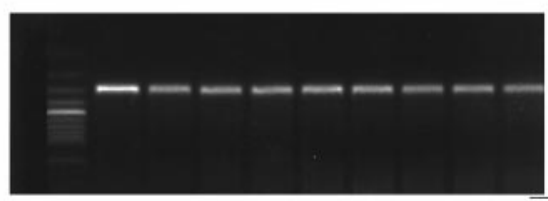

$\Leftarrow \mathbf{2 8 0}$ bp

\section{Caspase-3 (30 Cycles)}

MW Ast Ast Rat Rat Mo Mo Hip H3h H6h

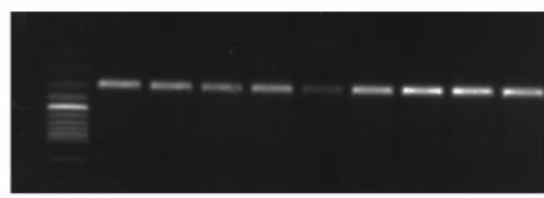

$\Leftarrow 300$ bp

\section{B-Actin (25 Cycles)}

MW Ast Ast Rat Rat Mo Mo Hip H3h H6h

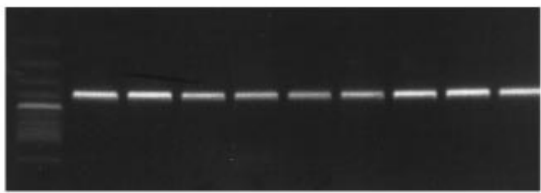

$\Leftarrow 380$ bp

Figure 5. Expression of caspase-1 $(A)$, caspase-3 $(B)$, and $\beta$-actin $(C)$ mRNA in rat hippocampal cultures determined by RT-PCR. cDNA from cultured cortical astrocytes (Ast, two samples), rat brain (Rat; striatum and septum), mouse brain (Mo; neocortex, two samples), hippocampal control cultures (Hip), hippocampal cultures treated for $3 \mathrm{hr}(\mathrm{H} 3 \mathrm{~h})$, or 6 $\mathrm{hr}(H 6 h)$ with staurosporine ( $30 \mathrm{nM})$ were amplified by 30 or 35 (Caspase$1), 30$ (Caspase-3), and 25 cycles of PCR ( $\beta$-Actin). Reaction products were separated by agarose gel electrophoresis and visualized with $0.1 \%$ ethidium bromide under UV illumination. MW: $100 \mathrm{bp}$ (top) to $1000 \mathrm{bp}$ (bottom) molecular weight ladder. Expected sizes of amplification products are indicated. $b p$, Base pairs.

\section{Intracellular superoxide production occurs downstream of caspase-1-like but upstream of caspase-3-like protease activity}

We then determined the effects of the caspase-1-like and caspase3-like protease inhibitors on staurosporine-induced superoxide production. A 60 min pretreatment with the caspase-1-like protease inhibitor Ac-YVAD-CHO $(10 \mu \mathrm{M})$ prevented the increase in superoxide production determined after $6 \mathrm{hr}$ of staurosporine
A

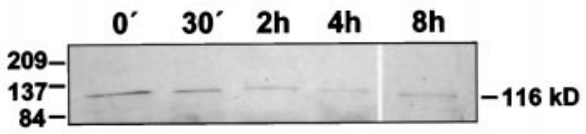

B
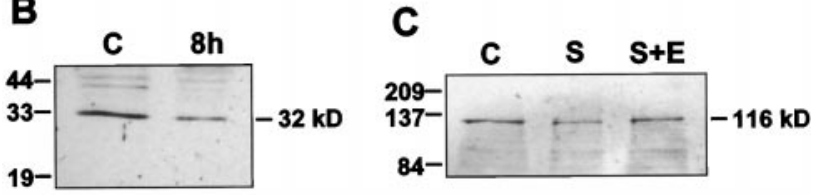

Figure 6. A, B, Evidence for the activation of caspase-3-like proteases during staurosporine-induced cell death demonstrated by Western blotting. A, Cultures were treated with staurosporine $(30 \mathrm{nM})$ for the indicated period of time $(0-8 \mathrm{hr})$, and $20 \mu \mathrm{g}$ of protein extract was separated by $10 \%$ SDS-PAGE. After blotting onto nitrocellulose membranes, immunodetection was performed using a mouse monoclonal antibody specific for uncleaved PARP (116 kDa). The experiment was performed in duplicate, with similar results. $B$, Cultures were treated for $8 \mathrm{hr}$ with staurosporine or vehicle, and $20 \mu \mathrm{g}$ of protein extract was separated by $12.5 \%$ SDS-PAGE. Immunodetection was performed using a rabbit polyclonal antibody specific for pro-caspase-3. The experiment was performed in duplicate, with similar results. $C$, Treatment with the antioxidant $( \pm)$ - $\alpha$-tocopherol prevents PARP degradation. Cultures were treated with vehicle [control $(C)$ ], staurosporine $(S)(30 \mathrm{nM})$, or staurosporine plus ( \pm$)$ - $\alpha$-tocopherol [vitamin E $(S+E) ; 100 \mu \mathrm{M}$ ] for $8 \mathrm{hr}$. Protein extract $(20 \mu \mathrm{g})$ was separated by $10 \%$ SDS-PAGE, proteins were blotted, and immunodetection was performed using the PARP antibody. Locations of molecular weight marker bands (in kilodaltons) are provided on the left side of each figure.

exposure (Fig. 9A). Ac-YVAD-CHO had no effect when added 2 $\mathrm{hr}$ after the addition of staurosporine. In contrast, a $60 \mathrm{~min}$ pretreatment with the caspase-3-like protease inhibitor AcDEVD-CHO $(10 \mu \mathrm{M})$ failed to reduce the staurosporine-induced increase in superoxide production (Fig. 9A).

Finally, we investigated the effect of the antioxidant $( \pm)-\alpha-$ tocopherol $(100 \mu \mathrm{M})$ on caspase-3-like protease activity. Treatment with $( \pm)-\alpha$-tocopherol $(100 \mu \mathrm{M})$ reduced the staurosporineinduced rise in caspase-3-like protease activity determined $6 \mathrm{hr}$ after addition of staurosporine, even when added $4 \mathrm{hr}$ after staurosporine (Fig. 9B). In addition, treatment with $( \pm)-\alpha-$ tocopherol $(100 \mu \mathrm{M})$ prevented the proteolytic degradation of the $116 \mathrm{kDa}$ PARP protein as demonstrated by Western blotting (Fig. $6 C$ ). As expected, a 60 min pretreatment with Ac-DEVD-CHO $(10 \mu \mathrm{M})$ prevented the increase in caspase-3-like protease activity (Fig. 9B). Reduction of caspase-3-like protease activity was also observed in cultures pretreated for 60 min with the caspase-1-like protease inhibitor Ac-YVAD-CHO $(10 \mu \mathrm{M})$ (Fig. $9 B)$.

\section{Nuclear fragmentation is not required for staurosporine-induced cell death}

Treatment with the caspase-3-like protease inhibitor Ac-DEVD$\mathrm{CHO}$ prevented the increase in caspase-3-like protease activity (Fig. $9 B$ ) but failed to reduce staurosporine-induced cell death (Fig. $1 B$ ). To determine whether staurosporine-treated neurons were able to die in the absence of nuclear fragmentation, hippocampal neurons were pretreated with Ac-DEVD-CHO (1-10 $\mu \mathrm{M}$ ), exposed to staurosporine ( $24 \mathrm{hr}$ exposure plus $24 \mathrm{hr}$ recovery), and then analyzed by Hoechst 33258 staining. Treatment with Ac-DEVD-CHO clearly reduced the percentage of cells showing nuclear fragmentation in concentrations as low as $1 \mu \mathrm{M}$ (Table 3). 

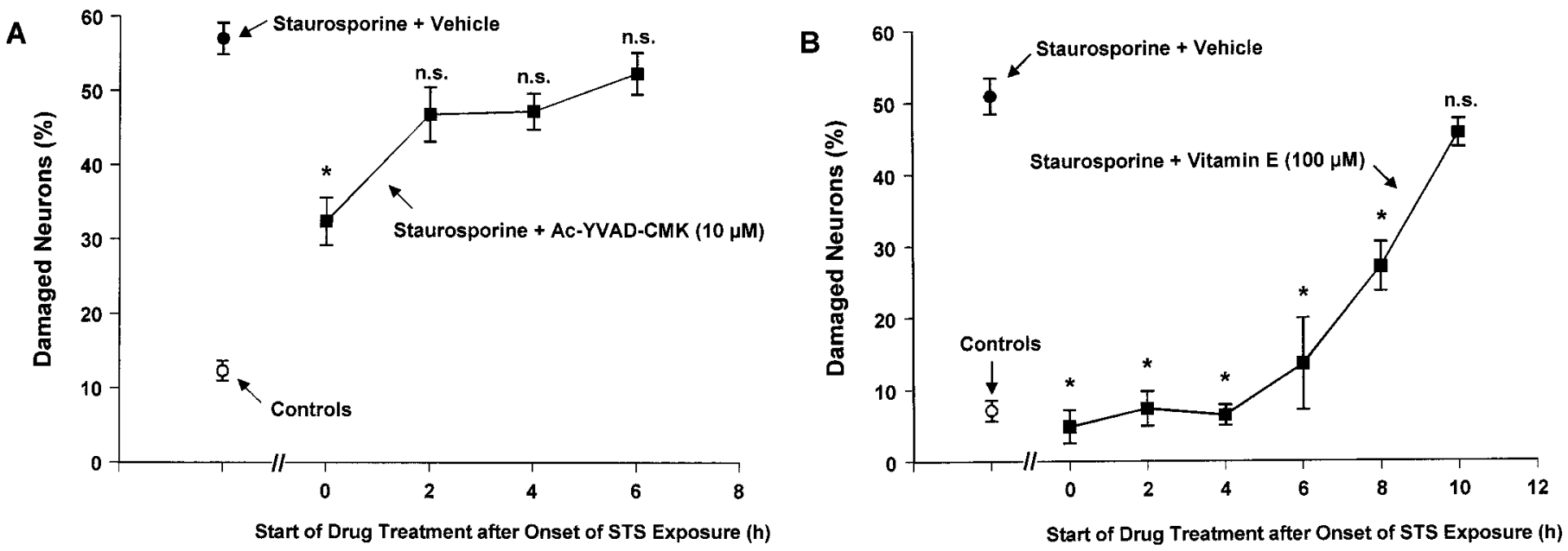

Figure 7. Delayed administration of the antioxidant ( \pm )- $\alpha$-tocopherol (vitamin E), but not of the caspase-1-like protease inhibitor Ac-YVAD-CMK, prevents staurosporine-induced cell death. $A$, Cultured rat hippocampal neurons were treated with Ac-YVAD-CMK $(10 \mu \mathrm{M})$ at various time points after the onset of the staurosporine exposure ( $30 \mathrm{nM}, 24 \mathrm{hr}$ ). Afterward, the staurosporine-containing medium was aspirated, drug treatment was discontinued, and cultures were washed and maintained for a further $24 \mathrm{hr}$ in astrocyte-conditioned culture medium. The percentage of damaged neurons was determined by trypan blue exclusion at the end of the recovery period. Data are mean \pm SEM from $n=8-12$ cultures in three separate experiments. $B$, Effect of delayed treatment with $( \pm)$ - $\alpha$-tocopherol $(100 \mu \mathrm{M})$. Data are mean \pm SEM from $n=8-16$ cultures in five separate experiments. Difference from respective vehicle-treated, staurosporine-exposed controls: ${ }^{*} p<0.05$. n.s., Not statistically significant.

\section{DISCUSSION}

Activation of caspases and increased formation of reactive oxygen species are believed to play central roles in the initiation and execution of PCD. In the present study, we characterized the time course of caspase activation and intracellular superoxide production in cultured rat hippocampal neurons exposed to the PCDinducing agent staurosporine. We demonstrated that staurosporine caused an early increase in a caspase-1-like activity and that this activity mediated a delayed increase in superoxide production. Pharmacological inhibition of both caspase-1-like activity and superoxide production rescued neurons from PCD. Finally, we showed that activation of caspase-3-like proteases occurred downstream of both processes but did not contribute to the actual cell death.

\section{Superoxide mediates staurosporine-induced neuronal apoptosis}

In agreement with previous reports, we found that antioxidants have the capacity to protect cultured neurons from apoptosis (Atabay et al., 1996; Dugan et al., 1996; Schulz et al., 1996; Prehn et al., 1997; Estévez et al., 1998) (Fig. 1A). Of note, the long-term survival studies performed in this investigation indicate that antioxidants not only delayed but in fact prevented neuronal degeneration. Our previous observation of the importance of superoxide in staurosporine-induced neuronal apoptosis, shown by the protective effect of SOD-1 overexpression (Prehn et al., 1997), was confirmed in the present study by the protective effect of the cell-permeant SOD-mimetic MnTBP (Fig. 1A). This correlated with the increase in intracellular superoxide production detected with the specific, oxidation-sensitive probe HEt (Bindokas et al., 1996).

The antioxidant $( \pm)$ - $\alpha$-tocopherol prevented the increase in superoxide production and neuronal death, even when added $4 \mathrm{hr}$ after the onset of the staurosporine exposure (Figs. $2 B, 7 B, 8$ ). This indicates that the mild elevation of intracellular superoxide production occurring in the first $4 \mathrm{hr}$ of staurosporine exposure was not sufficient to trigger cell death in hippocampal neurons. Because the antioxidant $( \pm)$ - $\alpha$-tocopherol does not directly scavenge superoxide, an increased generation of reactive oxygen species other than superoxide contributes to the increase in superoxide production and cell death. Surprisingly, delayed treatment with $( \pm)$ - $\alpha$-tocopherol $8 \mathrm{hr}$ after the onset of staurosporine exposure, i.e., at a time point when apoptosis-specific changes were evident, still led to a significant reduction in neuronal cell death (Fig. 7B).

Evidence has been presented that intracellular superoxide production during apoptotic injury is $\mathrm{Ca}^{2+}$-dependent and mitochondrial in origin (Ankarcrona et al., 1995; Zamzami et al., 1995; Bindokas et al., 1996; Prehn et al., 1997). An increase in superoxide production might be a consequence of mitochondrial depolarization (Zamzami et al., 1995). The voltage-sensitive probe TMRE partitions to the negatively charged mitochondrial matrix according to the Nernst equation and can be used to estimate changes in mitochondrial membrane potential (Ehrenberg et al., 1988). We could not detect a significant decrease in cellular TMRE fluorescence, indicative of mitochondrial depolarization, in the hippocampal neurons before ( 0.5 and $2 \mathrm{hr})$ or during $(8 \mathrm{hr}$ ) peak superoxide production (Table 2). Moreover, staurosporine-exposed hippocampal neurons still responded with mitochondrial TMRE release on depolarization with the protonophore FCCP. It is conceivable that only a subset of mitochondria depolarized during the exposure to staurosporine. Nevertheless, previous reports have suggested that mitochondrial depolarization is not required for the induction of apoptosis [Deckwerth and Johnson (1993); Kluck et al. (1997); Vander Heiden et al. (1997); Bossy-Wetzel et al. (1998); but see Mancini et al. (1997); Wadia et al. (1998)]. In fact, we observed an increased neuronal TMRE fluorescence during peak superoxide production (Table 2). An increase in mitochondrial volume or mitochondrial hyperpolarization might underlie this increase (Vander Heiden et al., 1997). 

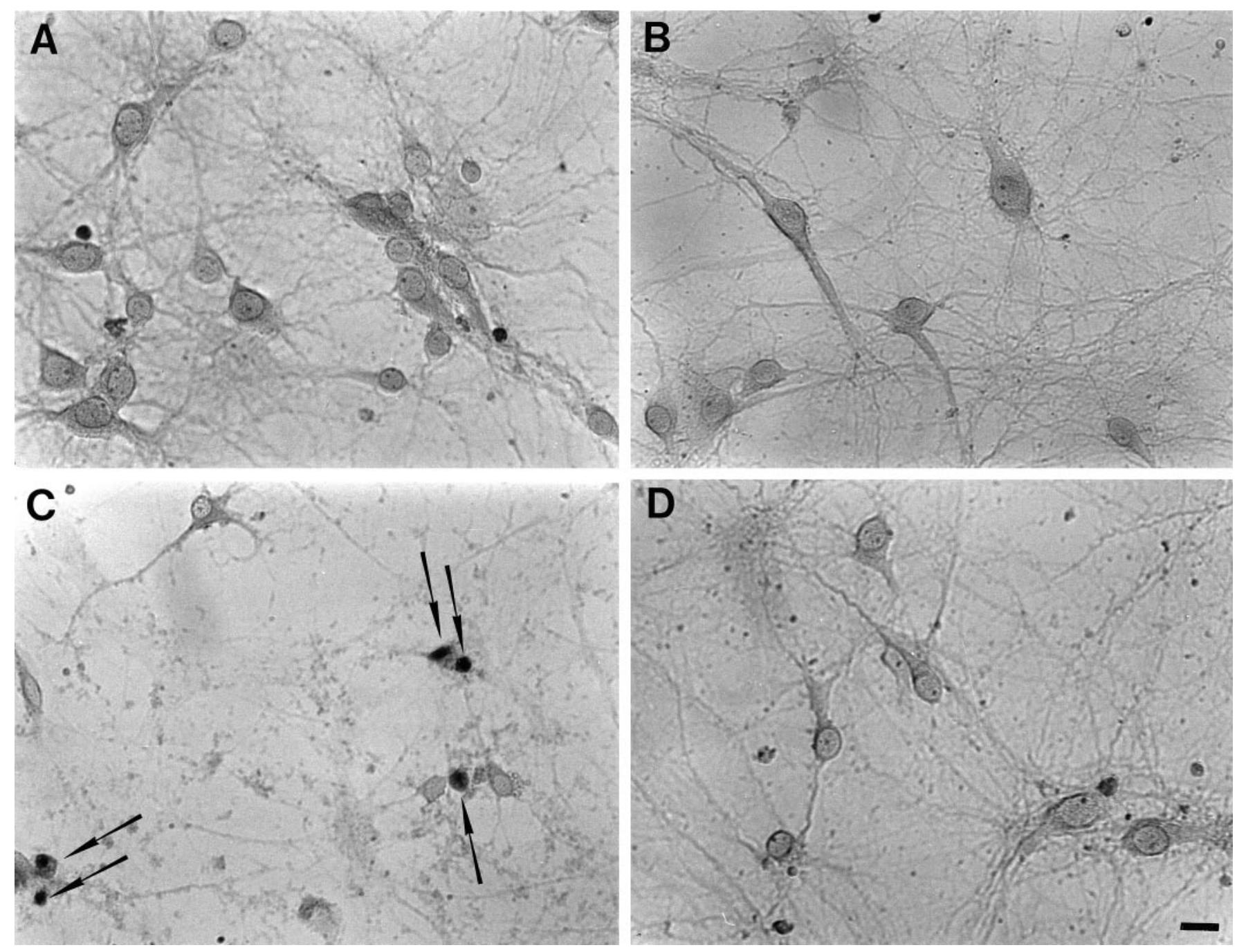

Figure 8. Phase-bright micrographs of rat hippocampal neurons stained with trypan blue: protective effect of a delayed ( \pm )- $\alpha$-tocopherol treatment. $A$, Control culture treated for $24 \mathrm{hr}$ with vehicle and maintained for a further $24 \mathrm{hr}$ in astrocyte-conditioned culture medium. $B$, Control culture treated with $( \pm)$ - $\alpha$-tocopherol $(100 \mu \mathrm{M})$ for $24 \mathrm{hr}$ and maintained for a further $24 \mathrm{hr}$ in astrocyte-conditioned medium. $C$, Culture exposed to staurosporine (30 $\mathrm{nM}, 24 \mathrm{hr}$ ) followed by $24 \mathrm{hr}$ of recovery. Note the appearance of shrunken, trypan blue-positive neurons in the culture (arrows). $D$, Culture exposed to staurosporine $(30 \mathrm{nM})$ for $24 \mathrm{hr}$ and treated with $( \pm)$ - $\alpha$-tocopherol $4 \mathrm{hr}$ after the onset of the staurosporine exposure. Afterward, the staurosporinecontaining medium was aspirated, drug treatment was discontinued, and the culture was maintained for a further $24 \mathrm{hr}$ in astrocyte-conditioned medium. Note the preservation of neuronal morphology in the majority of the hippocampal neurons. Scale bar, $20 \mu \mathrm{m}$.

\section{Caspases in staurosporine-induced neuronal apoptosis}

In the cultured rat hippocampal neurons, staurosporine induced a biphasic activation of caspases: an early activity characterized by cleavage of a substrate for caspase-1-like proteases (maximal activity $30 \mathrm{~min}$ after addition of staurosporine), followed by a delayed activity characterized by cleavage of a substrate for caspase-3-like proteases (peak activity $8 \mathrm{hr}$ after addition of staurosporine) (Fig. 4). Evidence for the delayed activation of caspase-3-like proteases was also obtained by Western blotting experiments (Fig. 6) [also see Taylor et al. (1997)]. Activation of caspases has been reported to occur during neuronal apoptosis after withdrawal of trophic support (Deshmukh et al., 1996; Schulz et al., 1996; Stefanis et al., 1996; Armstrong et al., 1997; Eldadah et al., 1997; Lynch et al., 1997; Miller et al., 1997) or excitotoxic injury (Du et al., 1997). A biphasic response during neuronal apoptosis similar to the one reported in the present study, however, has rarely been reported. In non-neuronal cells, sequential activation of caspase-1-like proteases followed by caspase-3-like proteases occurred during CD95-induced apoptosis of lymphocytes (Enari et al., 1996; Susin et al., 1997). Interestingly, CD95-induced apoptosis is also associated with increased oxidant stress and is partially impaired in caspase-1deficient mice (Kuida et al., 1995; Li et al., 1995; Zamzami et al., 1995).

Pharmacological inhibition of caspase-1-like protease activity blocked the staurosporine-induced increase in superoxide production, caspase-3-like protease activity, and cell death in the hippocampal neurons (Figs. 1B, 9), suggesting that caspase-1-like proteases act upstream of these processes. In contrast, although pharmacological inhibition of caspase-3-like activity suppressed the increase in caspase-3-like protease activity and prevented apoptosis-specific morphological alterations such as nuclear fragmentation, it did not prevent the increase in superoxide and did not result in improved cell survival (Figs. 1B, 9; Table 3). This dissociation of caspase-3-like activity and cell death has been reported previously by other groups (Stefanis et al., 1996; Lynch 
A

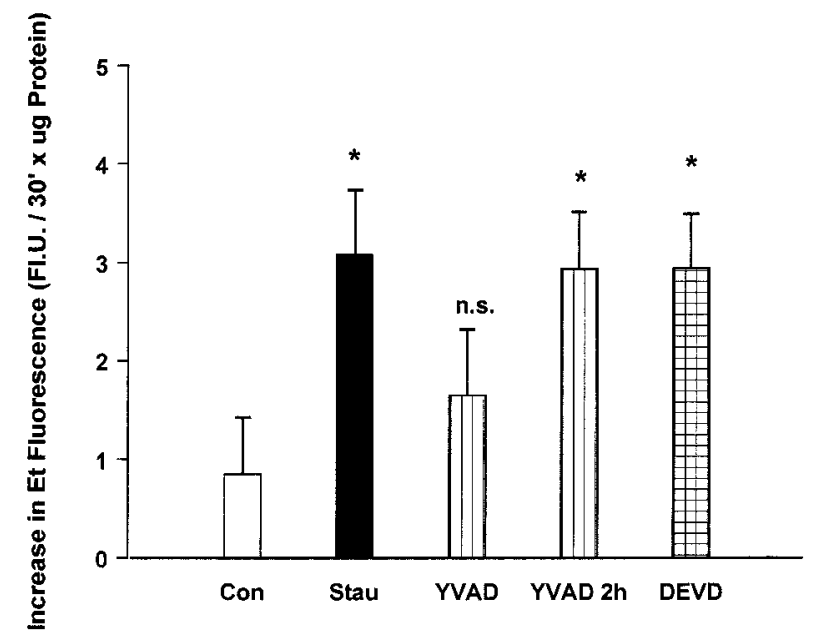

B

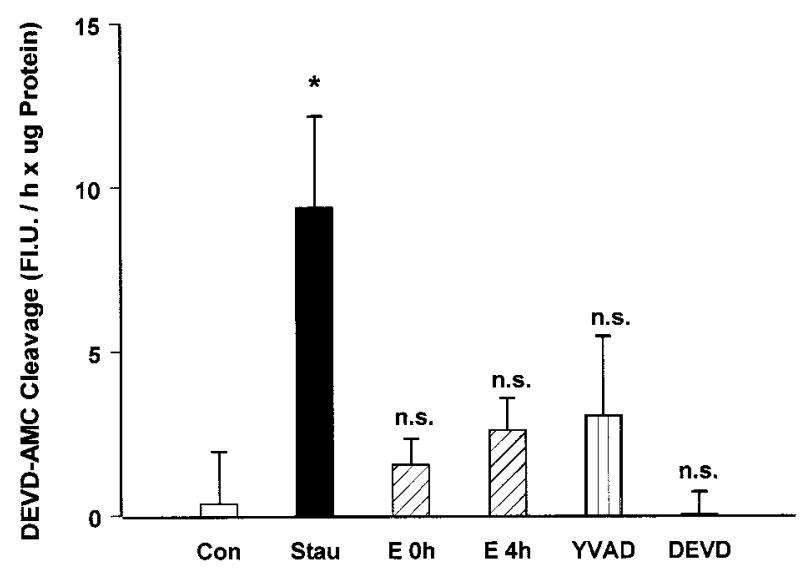

Figure 9. A, Inhibition of superoxide production by the caspase-1-like protease inhibitor Ac-YVAD-CHO. Cytosolic extracts were prepared from hippocampal cultures treated for $6 \mathrm{hr}$ with vehicle (Con), staurosporine (Stau) (30 nM), staurosporine plus Ac-YVAD-CHO (YVAD) (10 $\mu$ M, $60 \mathrm{~min}$ pretreatment), staurosporine plus Ac-YVAD-CHO added after $2 \mathrm{hr}(Y V A D 2 h)$, or staurosporine plus Ac-DEVD-CHO (DEVD) (10 $\mu \mathrm{M}, 60 \mathrm{~min}$ pretreatment). Hydroethidine was added during the last $30 \mathrm{~min}$ of the exposure in a concentration of $5 \mu \mathrm{g} / \mathrm{ml}$. Et fluorescence of cellular extracts was quantified using a fluorescence microplate reader. Data are mean \pm SEM from $n=8-10$ cultures in two separate experiments. Different from vehicle-treated controls: ${ }^{*} p<0.05$. n.s., Not statistically significant. $B$, Inhibition of caspase-3-like protease activity by the antioxidant $( \pm)$ - $\alpha$-tocopherol and by the caspase inhibitors Ac-YVAD-CHO and Ac-DEVD-CHO. Cytosolic protein extracts were prepared from hippocampal cultures treated for $6 \mathrm{hr}$ with vehicle (Con), staurosporine (Stau) (30 nM), staurosporine plus $( \pm)$ - $\alpha$-tocopherol $(E 0 h)(100 \mu \mathrm{M})$, staurosporine plus $( \pm)$ - $\alpha$-tocopherol added after $4 \mathrm{hr}(E 4 h)$, staurosporine plus Ac-YVAD-CHO (YVAD) (10 $\mu \mathrm{M}, 60$ min pretreatment), or staurosporine plus Ac-DEVD-CHO (DEVD) (10 $\mu \mathrm{M}$, 60 min pretreatment). Caspase-3-like activity was determined as described in the legend to Figure 4 . Data are mean \pm SEM from $n=10-12$ cultures in two separate experiments. Different from vehicle-treated controls: ${ }^{*} p<0.05$. n.s., Not statistically significant.

\section{Table 3. The caspase-3-like protease inhibitor Ac-DEVD-CHO inhibits staurosporine-induced nuclear fragmentation}

\begin{tabular}{lcc} 
Treatment & Apoptotic nuclei (\%) & $n$ \\
\hline Vehicle (DMSO) & $6.7 \pm 1.7$ & 4 \\
Vehicle $+10 \mu \mathrm{M}$ Ac-DEVD-CHO & $1.2 \pm 1.4$ & 4 \\
& & \\
Staurosporine & $35.8 \pm 4.5$ & 4 \\
Staurosporine $+1 \mu \mathrm{M}$ Ac-DEVD-CHO & $12.3 \pm 3.8^{*}$ & 4 \\
Staurosporine $+10 \mu \mathrm{M}$ Ac-DEVD-CHO & $9.3 \pm 4.5^{*}$ & 4
\end{tabular}

Cultured rat hippocampal neurons were pretreated for 60 min with Ac-DEVD-CHO or vehicle and were then exposed to $30 \mathrm{~nm}$ staurosporine for $24 \mathrm{~h}$. Afterward, the staurosporine-containing medium was aspirated, drug treatment was discontinued, and cultures were washed and maintained for an additional $24 \mathrm{~h}$ in astrocyteconditioned culture medium. The percentage of nuclear fragmentation was determined after Hoechst 33258 staining of nuclear chromatin. Data are means \pm SEM. *Difference from vehicle-treated, staurosporine-exposed controls: $p<0.05$.

et al., 1997; Taylor et al., 1997). Still, there is evidence that inhibition of caspase-3-like protease activity has protective effects in some forms of neuronal apoptosis (Du et al., 1997; Eldadah et al., 1997; Troy et al., 1997). These contradictory findings suggest the existence of multiple pathways in neuronal apoptosis (Miller et al., 1997; Park et al., 1998). In staurosporine-induced PCD of hippocampal neurons, the role of caspase-3-like proteases might be restricted to the dismantling and packaging of cells. The cell death itself is mediated by other effectors, such as increased generation of superoxide. Interestingly, delayed administration of $( \pm)$ - $\alpha$-tocopherol $4 \mathrm{hr}$ after the addition of staurosporine not only prevented the large increase in intracellular superoxide production occurring after $8 \mathrm{hr}$ (Fig. $2 B$ ), but also reduced the activation of caspase-3-like proteases (Fig. 9B). On the other hand, inhibition of caspase-3-like activity failed to reduce the increase in intracellular superoxide production (Fig. $8 A$ ), suggesting that intracellular superoxide production occurred upstream from activation of caspase-3-like proteases.

In conclusion, staurosporine-induced apoptosis of cultured rat hippocampal neurons involves caspase-1-like proteases as upstream initiators of cell death and increased production of superoxide as a main downstream effector. Caspase-3-like proteases appear to be involved in ensuring an orderly cell death rather than in execution of cell death. Because neurons are very susceptible to oxidant stress, it remains to be shown whether this is a neuron-specific phenomenon or whether it also holds true for PCD in other cell types.

\section{REFERENCES}

Alnemri ES, Livingston DJ, Nicholson DW, Salvesen G, Thornberry NA, Wong WW, Yuan J (1996) Human ICE/CED-3 protease nomenclature. Cell 87:171.

Ankarcrona M, Dypbukt JM, Bonfoco E, Zhivotovsky B, Orrenius S, Lipton SA, Nicotera P (1995) Glutamate-induced neuronal death: a succession of necrosis and apoptosis depending on mitochondrial function. Neuron 15:961-973.

Armstrong RC, Aja TJ, Hoang KD, Gaur S, Bai X, Alnemri ES, Litwack G, Karanewsky DS, Fritz LC, Tomaselli KJ (1997) Activation of the CED3/ICE-related protease CPP32 in cerebellar granule neurons undergoing apoptosis but not necrosis. J Neurosci 15:553-562.

Atabay C, Cagnoli CM, Kharlamov E, Ikonomovic MD, Manev H (1996) Removal of serum from primary cultures of cerebellar granule neurons induces oxidative stress and DNA fragmentation: protection with antioxidants and glutamate receptor antagonists. J Neurosci Res 43:465-475.

Bertrand R, Solary E, O'Connor P, Kohn KW, Pommier Y (1994) Induction of a common pathway of apoptosis by staurosporine. Exp Cell Res 211:314-321.

Bindokas VP, Jordan J, Lee CC, Miller RJ (1996) Superoxide production in rat hippocampal neurons: sensitive imaging with ethidine. J Neurosci 16:1324-1336.

Bossy-Wetzel E, Newmeyer DD, Green DR (1998) Mitochondrial cytochrome $c$ release in apoptosis upstream of DEVD-specific caspase activation and independently of mitochondrial transmembrane depolarization. EMBO J 17:37-49. 
Bredesen DE (1995) Neural apoptosis. Ann Neurol 38:839-851.

Cohen GM (1997) Caspases: the executioners of apoptosis. Biochem J 326:1-16.

Deckwerth TL, Johnson Jr EM (1993) Temporal analysis of events associated with programmed cell death (apoptosis) of sympathetic neurons deprived of nerve growth factor. J Cell Biol 123:1207-1222.

Deshmukh M, Vasilakos J, Deckwerth TL, Lampe PA, Shivers BD, Johnson Jr EM (1996) Genetic and metabolic status of NGF-deprived sympathetic neurons saved by an inhibitor of ICE family proteases. J Cell Biol 135:1341-1354.

Du Y, Bales KR, Dodel RC, Hamilton-Byrd E, Horn JW, Czilli DL, Simmons LK, Ni B, Paul SM (1997) Activation of a caspase-3-related cysteine protease is required for glutamate-mediated apoptosis of cultured cerebellar granule neurons. Proc Natl Acad Sci USA 94:11657-11662.

Dugan LL, Gabrielsen JK, Yu SP, Lin T-S, Choi DW (1996) Buckminsterfullerenol free radical scavengers reduce excitotoxic and apoptotic death of cultured cortical neurons. Neurobiol Dis 3:129-135.

Ehrenberg B, Montana V, Wie MD, Wuskell JP, Loew LM (1988) Membrane potential can be determined in individual cells from the nernstian distribution of cationic dyes. Biophys J 53:785-794.

Eldadah BA, Yakovlev AG, Faden AI (1997) The role of CED-3-related cysteine proteases in apoptosis of cerebellar granule cells. J Neurosci 17:6105-6113.

Enari M, Talanian RV, Wong WW, Nagata S (1996) Sequential activation of ICE-like and CPP32-like proteases during Fas-mediated apoptosis. Nature 380:723-726.

Enari M, Sakahira H, Yokoyama H, Okawa K, Iwamatsu A, Nagata S (1998) A caspase-activated DNase that degrades DNA during apoptosis, and its inhibitor ICAD. Nature 391:43-50.

Estévez AG, Spear N, Manual SM, Radi R, Henderson CE, Barbeito L, Beckman JS (1998) Nitric oxide and superoxide contribute to motor neuron apoptosis induced by trophic factor deprivation. J Neurosci 18:923-931.

Falcieri E, Martelli AM, Bareggi R, Cataldi A, Cocco L (1993) The protein kinase inhibitor staurosporine induces morphological changes typical of apoptosis in MOLT-4 cells without concomitant DNA fragmentation. Biochem Biophys Res Commun 193:19-25.

Fernandes-Alnemri T, Litwack G, Alnemri ES (1994) cpp32, a novel human apoptotic protein with homology to Caenorhabditis elegans cell death protein CED-3 and mammalian interleukin- $\beta$ converting enzyme. J Biol Chem 269:30761-30764.

Gagliardini V, Fernandez P-A, Lee RKK, Drexler HCA, Rotello RJ, Fishman MC, Yuan J (1994) Prevention of vertebrate neuronal death by the $\mathrm{crmA}$ gene. Science 263:826-828.

Greenlund LJS, Deckwerth TL, Johnson Jr EM (1995) Superoxide dismutase delays neuronal apoptosis: a role for reactive oxygen species in programmed cell death. Neuron 14:303-315.

Hengartner MO, Horvitz RH (1994) C. elegans cell survival gene ced-9 encodes a functional homolog of the mammalian protooncogene $b c l-2$. Cell 76:665-676.

Horvitz HR, Shaham S, Hengartner MO (1994) The genetics of programmed cell death in the nematode Caenorhabditis elegans. Cold Spring Harb Symp Quant Biol 59:377-385.

Jacobson M, Burne JF, King MP, Miyashita T, Reed JC, Raff MC (1993) Bcl-2 blocks apoptosis in cells lacking mitochondrial DNA. Nature 361:365-369.

Jordan J, Ghadge GD, Prehn JHM, Toth P, Roos RP, Miller RJ (1995) Expression of human $\mathrm{Cu} / \mathrm{Zn}$ superoxide dismutase inhibits the death of sympathetic neurons caused by withdrawal of nerve growth factor. Mol Pharmacol 47:1095-1100.

Jordan J, Galindo MF, Miller RJ (1997) Role of calpain- and interleukin- $1 \beta$ converting enzyme-like proteases in the $\beta$-amyloidinduced death of rat hippocampal neurons in culture. J Neurochem 68:1612-1621.

Kane DJ, Sarafian TA, Anton R, Hahn H, Gralla EB, Valentine JS, Ord T, Bredesen DE (1993) Bcl-2 inhibition of neural death: decreased generation of reactive oxygen species. Science 262:1274-1277.

Kluck RM, Bossy-Wetzel E, Green DR, Newmeyer DD (1997) The release of cytochrome c from mitochondria: a primary site for $\mathrm{Bcl}-2$ regulation of apoptosis. Science 275:1132-1136.

Koh J-Y, Wie MB, Gwag BJ, Sensi SL, Canzoniero LMT, Demaro J, Csernansky C, Choi DW (1995) Staurosporine-induced neuronal apoptosis. Exp Neurol 135:153-159.

Kuida K, Lippke JA, Ku G, Harding MW, Livingston DJ, Su MS-S,
Flavell RA (1995) Altered cytokine expression and apoptosis in mice deficient in interleukin-1 $\beta$ converting enzyme. Science 267:2000-2003.

Kuida K, Zheng TS, Na SQ, Kuan CY, Yang D, Karasuyama H, Rakic P, Flavell RA (1996) Decreased apoptosis in the brain and premature lethality in CPP32-deficient mice. Nature 384:368-372.

Li P, Allen H, Banerjee S, Franklin S, Herzog L, Johnston C, McDowell J, Paskind M, Rodman L, Salfeld J, Towine E, Tracey D, Wardwell S, Wei F-Y, Wong W, Kamen R, Seshardi T (1995) Mice deficient in IL- $1 \beta$-converting enzyme are defective in production of mature IL-1 $\beta$ and resistant to endotoxic shock. Cell 80:401-412.

Lynch T, Vasilakos JP, Raser K, Keane KM, Shivers BD (1997) Inhibition of the interleukin- $1 \beta$ converting enzyme family rescues neurons from apoptotic death. Mol Psychiatry 2:227-238.

Mancini M, Anderson BO, Caldwell E, Sedghinasab M, Paty PB, Hockenberry DM (1997) Mitochondrial proliferation and paradoxical membrane depolarization during terminal differentiation and apoptosis in a human colon carcinoma cell line. J Cell Biol 138:449-469.

Margolin N, Raybuck SA, Wilson KP, Chen W, Fox T, Gu Y, Livingston DJ (1997) Substrate and inhibitor specificity of interleukin-1 $\beta$ converting enzyme and related caspases. J Biol Chem 272:7223-7228.

Miller TM, Moulder KL, Knudson CM, Creedon DJ, Deshmukh M, Korsmeyer SJ, Johnson Jr EM (1997) Bax deletion further orders the cell death pathway in cerebellar granule cells and suggests a caspaseindependent pathway to cell death. J Cell Biol 139:205-217.

Milligan CE, Prevette D, Yaginuma H, Homma S, Cardwell C, Fritz LC, Tomaselli KJ, Oppenheim RW, Schwartz LM (1995) Peptide inhibitors of the ICE protease family arrest programmed cell death of motoneurons in vivo and in vitro. Neuron 15:385-393.

Ni B, Wu X, Du Y, Su Y, Hamilton-Byrd E, Rockey PK, Rosteck Jr P, Poirier GG, Paul SM (1997) Cloning and expression of a rat brain interleukin-1 $\beta$-converting enzyme (ICE)-related protease (IRP) and its possible role in apoptosis of cultured cerebellar granule neurons. J Neurosci 17:1561-1569.

Oppenheim RW (1991) Cell death during development of the nervous system. Annu Rev Neurosci 14:453-501.

Park DS, Morris EJ, Stefanis L, Troy CM, Shelanski ML, Geller HM, Greene LA (1998) Multiple pathways of neuronal death induced by DNA-damaging agents, NGF deprivation, and oxidative stress. J Neurosci 18:830-840.

Prehn JHM, Jordan J, Ghadge GD, Preis E, Galindo MF, Roos RP, Krieglstein J, Miller RJ (1997) $\mathrm{Ca}^{2+}$ and reactive oxygen species in staurosporine-induced neuronal apoptosis. $\mathrm{J}$ Neurochem 68: $1679-1685$.

Rothe G, Valet G (1990) Flow cytometric analysis of respiratory burst activity in phagocytes with hydroethidine and $2^{\prime}, 7^{\prime}$-dichlorofluorescin. J Leukocyte Biol 47:440-448.

Salvesen GS, Dixit VM (1997) Caspases: intracellular signaling by proteolysis. Cell 91:443-446.

Schulz JB, Weller M, Klockgether T (1996) Potassium deprivationinduced apoptosis of cerebellar granule neurons: a sequential requirement for new mRNA and protein synthesis, ICE-like protease activity, and reactive oxygen species. J Neurosci 16:4696-4706.

Semkova I, Wolz P, Schilling M, Krieglstein J (1996) Selegiline enhances NGF synthesis and protects central nervous system (CNS) neurons from excitotoxic and ischemic damage. Eur J Pharmacol 315:19-30.

Sengpiel B, Preis E, Krieglstein J, Prehn JHM (1998) NMDA-induced superoxide production and neurotoxicity in cultured rat hippocampal neurons: role of mitochondria. Eur J Neurosci 10:1903-1910.

Stefanis L, Park DS, Yun C, Yan I, Farinelli SE, Troy CM, Shelanski ML, Greene LA (1996) Induction of CPP32-like activity in PC12 cells by withdrawal of trophic support. J Biol Chem 271:30663-30671.

Susin SA, Zamzami N, Castedo M, Daugas E, Wang H-G, Geley S, Fassy F, Reed JC, Kroemer G (1997) The central executioner of apoptosis: multiple connections between protease activation and mitochondria in Fas/APO-1/CD95- and ceramide-induced apoptosis. J Exp Med 186:25-37.

Taylor J, Gatchalian CL, Keen G, Rubin LL (1997) Apoptosis in cerebellar granule neurons: involvement of interleukin-1 $\beta$ converting enzyme-like proteases. J Neurochem 68:1598-1605.

Thompson CB (1995) Apoptosis in the pathogenesis and treatment of disease. Science 267:1456-1462.

Thornberry NA, Bull HG, Calaycay JR, Chapman KT, Howard AD, Kostura MJ, Miller DK, Molineaux SM, Weidner JR, Aunins J, Elliston KO, Ayala JM, Casano FJ, Chin J, Ding GJF, Egger LA, Gaffney EP, Limjuco G, Paylha OC, Raju SM, Rolando AM, Salley 
JP, Yamin TT, Lee TD, Shively JE, MacCross M, Mumford RA, Schmidt JA, Tocci MJ (1992) A novel heterodimeric cysteine protease is required for interleukin- $1 \beta$ processing in monocytes. Nature 356:768-774.

Troy CM, Stefanis L, Prochiantz A, Greene LA, Shelanski ML (1996) The contrasting roles of ICE family proteases and interleukin-1-beta in apoptosis induced by trophic factor withdrawal and by copper/zinc superoxide dismutase downregulation. Proc Natl Acad Sci USA 93:5635-5640.

Troy CM, Stefanis L, Greene LA, Shelanski ML (1997) Nedd2 is required for apoptosis after trophic factor withdrawal, but not superoxide dismutase (SOD1) downregulation, in sympathetic neurons and PC12 cells. J Neurosci 17:1911-1918.

Vander Heiden MG, Chandel NS, Williamson EK, Schumacker PT, Thompson CB (1997) Bcl- $\mathrm{x}_{1}$ regulates the membrane potential and volume homeostasis of mitochondria. Cell 91:627-637.
Wadia JS, Chalmers-Redman RME, Ju WJH, Carlile GW, Phillips JL, Fraser AD, Tatton WG (1998) Mitochondrial membrane potential and nuclear changes in apoptosis caused by serum and nerve growth factor withdrawal: time course and modification by (-)-deprenyl. J Neurosci 18:932-947.

Yuan J, Shaham S, Ledoux S, Ellis HM, Horvitz HR (1993) The $C$. elegans cell death gene ced-3 encodes a protein similar to mammalian interleukin-1 $\beta$-converting enzyme. Cell 75:641-652.

Zamzami N, Marchetti P, Castedo M, Decaudin D, Macho A, Hirsch T, Susin SA, Petit PX, Mignotte B, Kroemer G (1995) Sequential reduction of mitochondrial transmembrane potential and generation of reactive oxygen species in early programmed cell death. J Exp Med 182:367-377.

Zou H, Henzel WJ, Liu X, Lutschg A, Wang X (1997) Apaf-1, a human protein homologous to $C$. elegans CED-4, participates in cytochrome c-dependent activation of caspase-3. Cell 90:405-413. 